\title{
Reversible and Irreversible Loss of Fc Receptor Function of Human Monocytes as a
}

\section{Consequence of Interaction with Immunoglobulin G}

\author{
R. J. Kurlander, Myrtle Bell Lane Laboratory, Department of Medicine, Duke \\ University Medical Center, Durham, North Carolina 27710
}

\begin{abstract}
A B S T RACT The effects of IgG in different configurations on the $\mathrm{F}_{\mathrm{c}}$ receptor function of human monocytes were studied. Receptor function was assessed by quantitating immune adherence and/or ingestion of human erythrocytes coated with IgG anti-D antibody. Monomeric IgGl in solution inhibited the $F_{c}$ receptor function of monocytes, but this function was restored completely after washing. In contrast, monomeric IgG that was adsorbed nonspecifically to a plastic surface inhibited the $\mathrm{F}_{\mathrm{c}}$ receptor function of monocytes even after washing away unbound IgG1. This loss of function could be blocked by sodium azide and was reversed when the IgG adsorbed to plastic was degraded by trypsin, suggesting that loss of function was the reversible consequence of localized binding of most of the monocyte's receptors at the point of contact with immobilized IgG1.
\end{abstract}

Fluid-phase aggregates of $\operatorname{IgGl}$ also reduced the $\mathrm{Fc}$ receptor function of monocytes as a consequence of direct binding to the monocyte surface. High concentrations of purified aggregates rapidly reduced $\mathrm{Fc}$ receptor function but function was reversed by trypsin even after incubation for $18 \mathrm{~h}$. Lower concentrations of aggregates reduced $\mathrm{Fc}$ receptor function more slowly, but after $18 \mathrm{~h}$ of incubation, lost function was not restored by trypsin treatment. Because the transition from reversible to irreversible loss was blocked by sodium azide, an energy-dependent process of ingestion, shedding or denaturation of receptors is responsible for this irreversible loss of $\mathrm{Fc}$ receptor function. Rabbit IgG anti-human IgG bound to IgG adsorbed to the surface of monocytes also mediated a loss of $\mathrm{Fc}$ receptor function as a result of the binding of $F_{C}$ receptors to the $F_{C}$ portion of the rabbit IgG molecule, a process analogous to the binding of aggregated IgG. After irreversible depletion of $\mathrm{FC}$ receptor function by anti-IgG, partial

Portions of this work were presented to the American Society of Hematology, Phoenix, Ariz., December 1979.

Received for publication 7 March 1980 and in revised form 30 April 1980. recovery of function was detectable within $12-24 \mathrm{~h}$ of incubation in vitro, and this recovery was blocked by cycloheximide, suggesting that new receptor synthesis was required for restoration of function.

\section{INTRODUCTION}

The destruction of erythrocytes coated with IgG antibody by reticuloendothelial cells in vitro $(1,2)$ and in vivo $(3,4)$ is mediated by receptors for the $F c$ portion of IgG. Variations in the quantity $(2,5)$, configuration (5), and subclass $(6,7)$ of the antibody coating of the erythrocytes have been shown to influence profoundly the rate of leukocyte-mediated erythrocyte destruction. In addition, recent studies suggest that variations in reticuloendothelial function also influence $F c$ receptormediated immune clearance. Patients with systemic lupus erythematosus (8), nephritis (9), vasculitis (9), or Sjögren's syndrome (10) sequester and destroy erythrocytes coated with IgG antibody in their spleen more slowly than normal volunteers. This reduction in $F_{c}$ receptor function may be a primary disorder contributing to tissue damage in these diseases $(8,10)$ or may be due to interference with $\mathrm{Fc}$ receptor function by immune complexes containing IgG $(9,11)$. In the following studies in vitro, we demonstrate that complexes containing IgG can reversibly reduce $\mathrm{Fc}$ receptor function of human monocytes, and that this process proceeds by an energy-dependent step(s) to the irreversible loss of receptor function. This process of receptor degradation may be of importance in the pathophysiology of a variety of disease states.

\section{METHODS}

Dulbecco's phosphate-buffered saline $(\mathrm{PBS})^{1}(\mathrm{pH} 7.4)$, Newman-Tytell serumless medium (N-T), RPMI 1640, fetal calf

\footnotetext{
${ }^{1}$ Abbreviations used in this paper: EA, human erythrocytes coated with IgG anti-D antibody; EA papain, papain-treated EA; FCS, fetal calf serum; N-T, Newman-Tytell serumless medium; PBS, Dulbecco's phosphate-buffered saline; $\mathrm{P}+\mathrm{S}$, penicillin and streptomycin solution.
} 
serum (FCS), and penicillin and streptomycin solution ( $P$ $+\mathrm{S})(10,000 \mathrm{U} / \mathrm{ml}$ and $10,000 \mu \mathrm{g} / \mathrm{ml}$, respectively) were obtained from Gibco Laboratories, Grand Island Biological Co., Grand Island, N. Y. Latex beads $(0.8 \mathrm{mM})$, cycloheximide, pepsin $(1: 10,000)$, papain (two times crystallized in $0.05 \mathrm{M}$ sodium acetate), glutaraldehyde (25\%), and pancreatic trypsin type II were obtained from Sigma Chemical Co., St. Louis, Mo. Sodium heparin was obtained from Upjohn Co. (Kalamazoo, Mich.).

Monoclonal human IgG was obtained from the serum of a single patient with multiple myeloma. The IgGl was precipitated in a $50 \%$ saturated ammonium sulfate solution, dialyzed free of ammonium sulfate, and purified by ion exchange chromatography using DEAE cellulose and a $0.005 \mathrm{M}$ phosphate buffer at pH 8.0. The IgG was collected, concentrated by vacuum dialysis, and stored at $4^{\circ} \mathrm{C}$ with $0.01 \%$ sodium azide. Azide was removed by dialysis against PBS before use. The concentration of IgGl in these fractions was calculated based on the absorbance of light at $280 \mu \mathrm{m}$, assuming an extinction coefficient $\left(\mathrm{E}_{1}^{1 \%} \mathrm{~cm}\right)$ of 13.3 for IgG. Plastic microtiter wells coated with IgG1 were prepared by incubation with a $10-\mathrm{mg} / \mathrm{ml}$ solution of monomeric IgGl for 18 $\mathrm{h}$ at $4^{\circ} \mathrm{C}$. Coated surfaces were then washed with PBS 10 times to remove unbound IgGl.

Preparation of IgG1 aggregates. Heat-treated IgG1 was prepared by incubation of an $\mathrm{IgGl}$ solution $(20 \mathrm{mg} / \mathrm{ml})$ at $63^{\circ} \mathrm{C}$ for $20 \mathrm{~min}$ (12). Purified IgGl aggregates were prepared by passing heat-treated IgGl through a $1 \times 80-\mathrm{cm}$ column of Sepharose 4B (Pharmacia Fine Chemicals, Div. of Pharmacia, Inc., Piscataway, N. J.) as described by others (13). Fractions with an apparent molecular weight larger than that of monomeric IgG were collected, pooled, and concentrated by vacuum dialysis.

Preparation of anti-IgG. Anti-IgG was prepared as described previously (14). A purified IgG fraction of this antiserum was prepared by passage of serum dialyzed against a $0.05-\mathrm{M}$ buffer through a $2.0 \times 20.0-\mathrm{cm}$ column of DEAE Affigel Blue (Bio-Rad Laboratories, Richmond, Calif.) using the method recommended by the manufacturer. $\mathrm{Fab}_{2}$ fragments were prepared by incubation of IgG with $1 \%$ by weight of pepsin in sodium acetate buffer at pH 4.4 for $36 \mathrm{~h}$. Fab fragments were then isolated by passage through a $100 \times 2$ cm Sephadex G-150 column (15) (Pharmacia Fine Chemicals).

Preparation of EA. Human $\mathrm{O}+$ erythrocytes were drawn and stored in Alsever's solution at $4^{\circ} \mathrm{C}$ for up to 2 wk. Erythrocytes to be sensitized with anti-D antibody were washed three times with PBS and $50 \mu \mathrm{l}$ of washed, packed erythrocytes were incubated with $20 \mu$ l of IgG anti-D antibody (RhoGam, Ortho Diagnostics, Inc., Raritan, N. J.) in $1 \mathrm{ml}$ of PBS at $37^{\circ} \mathrm{C}$ for $1 \mathrm{~h}$. EA then were washed four times and suspended in $12.5 \mathrm{ml}$ of RPMI 1640 plus $10 \%$ FCS.

Preparation of EA using papain-treated erythrocytes $\left(E A_{\text {papain }}\right)$. Papain-treated erythrocytes were prepared by incubating $50 \mu \mathrm{l}$ of packed erythrocytes suspended in $0.4 \mathrm{ml}$ of $0.15 \mathrm{M} \mathrm{NaCl}$ with $20 \mu \mathrm{l}$ of papain solution at room temperature for $30 \mathrm{~min}$. The erythrocytes were then washed four times with PBS, suspended in $1 \mathrm{ml}$ of PBS, and incubated with $5 \mu \mathrm{l}$ of anti-D antibody for $1 \mathrm{~h}$, washed, and suspended in $12.5 \mathrm{ml}$ of RPMI 1640 plus $10 \%$ FCS.

Preparation of EC43 was carried out using methods previously described (16). Human $\mathrm{O}+$ erythrocytes were incubated with an IgM cold agglutinin antibody and fresh human serum for $10 \mathrm{~min}$ at $4^{\circ} \mathrm{C}$ and $10 \mathrm{~min}$ at $37^{\circ} \mathrm{C}$, and then were washed thoroughly to remove remaining antibody and unbound complement components. Erythrocytes prepared in this fashion have been shown in the past to be coated with $\mathrm{C} 3$ and C4.

Preparation of human serum. $50 \mathrm{ml}$ of blood were drawn sterilely, cooled to $4^{\circ} \mathrm{C}$, and centrifuged at $12,000 \mathrm{~g}$ for $1 \mathrm{~min}$.
The plasma then was removed, incubated at $37^{\circ} \mathrm{C}$ for $30 \mathrm{~min}$, and serum was then separated mechanically from the clot.

Preparation of adherent monocytes. The mixture of erythrocytes, platelets, and leukocytes remaining after the removal of plasma above was mixed rapidly with $20 \mathrm{~cm}^{3}$ of RPMI 1640 containing $10 \mathrm{U} / \mathrm{ml}$ of sodium heparin. The cell suspension was then washed three times with RPMI 1640 and layered over $20 \mathrm{ml}$ of Ficoll-Hypaque (17) (Pharmacia Fine Chemicals). The tube was centrifuged at $500 \mathrm{~g}$ for $10 \mathrm{~min}$ and $1,000 \mathrm{~g}$ for $20 \mathrm{~min}$. The mixed mononuclear cells obtained from the interface were washed three times with RPMI and were resuspended in RPMI 1640 plus $20 \%$ FCS at a concentration of 5-10 × $10^{6}$ leukocytes $/ \mathrm{ml} .50-\mu$ l portions of this suspension were added to wells in sterile, 96-well, flat bottom microtiter plates (Falcon Labware, Div., Becton, Dickinson \& Co., Oxnard, Calif.), and incubated at $37^{\circ} \mathrm{C}$ for $30 \mathrm{~min}$. Each well was then washed six times with PBS to remove nonadherent lymphocytes, erythrocytes, and platelets. Greater than $90 \%$ of adherent leukocytes were monocytes, as judged by morphologic appearance and the capacity to ingest latex beads. Monocyte monolayers to be maintained in vitro for $<24 \mathrm{~h}$ were overlaid with RPMI 1640 with $10 \%$ FCS and $\mathrm{P}+\mathrm{S}$, but for more prolonged incubations monocytes were incubated in N-T medium with $20 \%$ autologous human serum and $\mathrm{P}+\mathrm{S}$ in a modification of the method of Johnson et al. (18) at $37^{\circ} \mathrm{C}$ in a moisturized $5 \% \mathrm{CO}_{2}$ incubator.

Incubation of monocytes with IgGl. Unless otherwise stated, incubations were performed by suspending mixed mononuclear cells $\left(5 \times 10^{6} / \mathrm{ml}\right)$ in medium containing IgG1 in $12 \times 75-\mathrm{mm}$ plastic tubes at $37^{\circ} \mathrm{C}$. After incubation, the cells were washed four times with PBS, resuspended in RPMI 1640 plus $20 \%$ FCS, and monocytes were allowed to adhere to microtiter plates, as described above, before assessment of Fc receptor (or other) function.

Incubation of monocytes with anti-IgG. Unless otherwise noted, incubation was performed by adding $50 \mu \mathrm{l}$ of antiIgG diluted $1: 250$ in RPMI 1640 to wells containing adherent, purified monocytes prepared as described above. After incubation, each well was washed a total of eight times with PBS to remove unbound anti-IgG before the assessment of $\mathrm{Fc}$ receptor function.

Trypsin treatment of adherent monocytes. Wells containing adherent monocytes were washed four times with PBS to remove unbound IgG1 or other protein, and $100 \mu \mathrm{l}$ of RPMI 1640 containing trypsin $(1 \mathrm{mg} / \mathrm{ml})$ was added to each well. The adherent cells were incubated at $37^{\circ} \mathrm{C}$ for $30 \mathrm{~min}$ and were washed again with PBS four times.

Assessment of $F c$ receptor function. Adherent monocytes with or without prior treatment with trypsin were overlaid with $50 \mu \mathrm{l}$ of a $0.4 \%$ suspension of EA in RPMI 1640 with $10 \%$ FCS and erythrocytes were permitted to sediment onto the adherent monocytes at $37^{\circ} \mathrm{C}$. After incubation for $60 \mathrm{~min}, 50 \mu \mathrm{l}$ of $0.5 \%$ glutaraldehyde in saline was added to each well for $10 \mathrm{~min}$ at room temperature and then each well was washed throughly with PBS, dried, and stained with Giemsa stain. Receptor activity was assessed in each well of the inverted microtiter plate at $\times 200$. Monocytes with three or more adherent erythrocytes or with one or more ingested, or partially ingested, erythrocytes were considered to possess $F_{c}$ receptor function. The percentage of monocytes with $\mathrm{Fc}$ receptor function was quantitated in each of three microtiter wells by scoring at least 100 cells for evidence of interaction with EA. The mean and standard deviation was calculated for each set of samples. Less than $1 \%$ of monocytes interacted with human erythrocytes not coated with IgG antibody.

Complement receptor function was measured by adding 50 $\mu \mathrm{l}$ of a $0.4 \%$ suspension of EC43 to microtiter wells containing adherent monocytes that had been washed as described 
above. Cells to be evaluated for complement receptor function were not treated with trypsin which is known to destroy complement receptor function (19). The cells in microtiter wells were incubated at $37^{\circ} \mathrm{C}$ for $1 \mathrm{~h}$, treated with glutaraldehyde, and stained as described above. The adherence of three or more erythrocytes to the monocyte membrane was considered evidence of complement receptor function. The percentage of monocytes possessing complement receptor function was measured in triplicate.

Phagocytic capacity of adherent monocytes was assessed by adding $50 \mu \mathrm{l}$ of a suspension $\left(1 \times 10^{8}\right.$ particles $\left./ \mathrm{cm}^{3}\right)$ of latex beads to microtiter wells containing adherent cells. Uningested particles were washed away after a $1-\mathrm{h}$ incubation at $37^{\circ} \mathrm{C}$ and 100 cells in each well were scored for evidence of latex ingestion under an inverted phase microscope at $\times 100$.

\section{RESULTS}

The effect of IgG1 adsorbed to plastic upon the $F_{C}$ receptor function of monocytes. When freshly prepared monocytes were permitted to adhere in microtiter wells, most (50-100\%) cells had demonstrable Fc receptor function as evidenced by the binding or ingestion of EA. However, monocytes permitted to adhere to microtiter wells coated with monoclonal IgG1 monomer had markedly inhibited $\mathrm{F}_{\mathrm{c}}$ receptor function. Inhibition was mediated by the Fc portion of IgGl because monocyte adherence to microtiter wells coated with $\mathrm{Fab}_{2}$ fragments of IgGl did not alter monocyte receptor function. The loss of $\mathrm{Fc}$ receptor function could be prevented if IgG-coated wells were treated with trypsin before the adherence of monocytes to the wells, and could be reversed by trypsin even after the monocytes had adhered to the IgG1-coated wells (Table I, experiment A). Similar inhibition of $F_{c}$ receptor function, which also could be reversed by treatment with trypsin, was produced when IgGl $(10 \mathrm{mg} / \mathrm{ml})$ was added to wells already containing monolayers of monocytes. Since the $\mathrm{Fc}$ receptor function of monocytes incubated with IgGl in test tubes and washed to remove unbound IgG before adherence of cells to wells was undiminished, this inhibition must be dependent in part upon
TABLE I

Effect of IgG1 Monomer on FC Receptor Function of Monocytes
Expt. A $\mathrm{F}_{\mathrm{c}}$ receptor function of monocytes adherent to plastic wells:

coated with IgGl monomer, coated with IgG monomer and then treated with trypsin before addition of monocytes, coated with $\mathrm{Fab}_{2}$ fragments of IgGl, without contact with IgG1

Expt. B Fc receptor function of adherent monocytes:

after incubation for $3 \mathrm{~h}$ in mictotiter wells with medium containing IgG1 monomer $10 \mathrm{mg} / \mathrm{ml}$, after incubation with IgG1 (10 $\mathrm{mg} / \mathrm{ml}$ ) monomer in a test tube for $3 \mathrm{~h}$ and washing before transfer to plastic wells, with medium without IgG1 monomer
$0.3 \pm 0.6 * \ddagger$

$97.0 \pm 2.1$

$95.3 \pm 2.5$

ND

$95.0 \pm 2.5$

ND

$90.3 \pm 2.1 \quad 97.0 \pm 2.1$

$96.0 \pm 1.7$

$50.3 \pm 3.1 \ddagger$

$95.0 \pm 2.5 \quad 94.0 \pm 1.7$

$94.7 \pm 2.5$

$* \pm \mathrm{SD}$.

$\$ P<0.001$.

$\mathrm{ND}$, not done.

the adherence of IgGl to the walls of the microtiter well (Table II).

The effect of aggregated IgG1 upon the Fc receptor function of monocytes. To prevent artifactual inhibition of $\mathrm{Fc}$ receptor function due to adsorption of free IgG to microtiter wells, in the remaining experiments

TABLE II

Effect of Purified Aggregates of IgG1 Upon Fc Receptor Function

\begin{tabular}{|c|c|c|c|c|}
\hline \multirow[b]{3}{*}{$\begin{array}{l}\text { Monocytes incubated in } \\
\text { medium containing purified } \\
\text { aggregates of IgG1 }\end{array}$} & \multicolumn{4}{|c|}{$\%$ Monocytes with $\mathrm{F}_{\mathrm{c}}$ receptor function after incubation } \\
\hline & \multicolumn{2}{|c|}{$1 \mathrm{~h}$} & \multicolumn{2}{|c|}{$18 \mathrm{~h}$} \\
\hline & $\begin{array}{l}\text { Without } \\
\text { trypsin } \\
\text { treatment }\end{array}$ & $\begin{array}{c}\text { Followed by } \\
\text { trypsin } \\
\text { treatment }\end{array}$ & $\begin{array}{l}\text { Without } \\
\text { trypsin } \\
\text { treatment }\end{array}$ & $\begin{array}{c}\text { Followed by } \\
\text { trypsin } \\
\text { treatment }\end{array}$ \\
\hline $6 \mathrm{mg} / \mathrm{ml}$ & $22.0 \pm 30 * \hbar$ & $87.7 \pm 2.5$ & $4.3 \pm 2.5 \ddagger$ & $84.3 \pm 10.6$ \\
\hline $0.6 \mathrm{mg} / \mathrm{ml}$ & $34.3 \pm 2.5^{*}$ & $61.7 \pm 5.0$ & $4.6 \pm 1.7 \ddagger$ & $9.3 \pm 0.6$ \\
\hline Medium alone & $87.3 \pm 2.6$ & $90.0 \pm 2.6$ & $91.7 \pm 3.8$ & $89.3 \pm 3.5$ \\
\hline
\end{tabular}

* $1 \mathrm{SD}$

$\ddagger P<0.001$. 
monocytes were treated with IgG1 by incubating mixed mononuclear cells with IgG1 in test tubes and washing away IgGl before the adherence of monocytes to microtiter wells.

Fc receptor function of monocytes was markedly reduced by incubation with solutions containing IgGl aggregates. High concentrations of purified aggregates $(6 \mathrm{mg} / \mathrm{ml})$ rapidly reduced $\mathrm{Fc}$ receptor function, however, even after incubation for $18 \mathrm{~h}$ this inhibition was reversed by treatment of monocytes with trypsin (Table II). Pretreatment of monocytes with trypsin (to uncover receptor sites blocked with cytophilic IgG) before the addition of aggregates did not prevent either the loss of receptor function or the restoration of function produced by a second incubation with trypsin after contact with purified aggregates (data not shown).

Monocytes incubated with a more dilute solution of purified aggregates $(0.6 \mathrm{mg} / \mathrm{ml})$ lost $\mathrm{Fc}$ receptor function more slowly, but after $18 \mathrm{~h}$ receptor loss was nearly complete and was not reversed by trypsin (Table II). A $10-\mathrm{mg} / \mathrm{ml}$ solution of heat-aggregated IgG (which contained $\sim 30 \%$ aggregated IgG1 and $70 \%$ monomeric IgG1) reduced $F_{c}$ receptor function minimally even after incubation for $18 \mathrm{~h}$; however, if after incubation with this solution for $1 \mathrm{~h}$ monocytes were washed and incubated in medium alone, $\mathrm{Fc}$ receptor function was lost over the following 17-h period (Table III). During the first $12 \mathrm{~h}$ of incubation after washing, this loss of $\mathrm{Fc}_{\mathrm{c}}$ receptor function could be partially reversed by trypsin but after longer intervals, loss of function could not be reversed (Fig. 1). The failure of crude heat-aggregated IgGl to reduce $\mathrm{Fc}$ receptor function appears to be due

TABLE III

Effect on Fc Receptor Function of Incubation with IgGI Followed by Washing and Incubation in Medium

$\%$ Monocytes with receptor function

Before trypsin After trypsin

Monocytes incubated for $18 \mathrm{~h}$ in medium containing heat-treated IgGl, $10 \mathrm{mg} / \mathrm{ml}$

$90.7 \pm 5.9^{*} \quad 93.7 \pm 4.6$

Monocytes washed and incubated in medium for $17 \mathrm{~h}$ after incubation for $1 \mathrm{~h}$ with monomeric IgG1, $10 \mathrm{mg} / \mathrm{ml}$, heat-treated $\operatorname{IgGl~} \mathrm{F}(\mathrm{ab})_{2}$, $10 \mathrm{mg} / \mathrm{ml}$, heat-treated IgGl, $10 \mathrm{mg} / \mathrm{ml}$; medium

$* \pm \mathrm{SD}$.

\$ Not done.

$\S$ Difference significant with $P<0.001$.

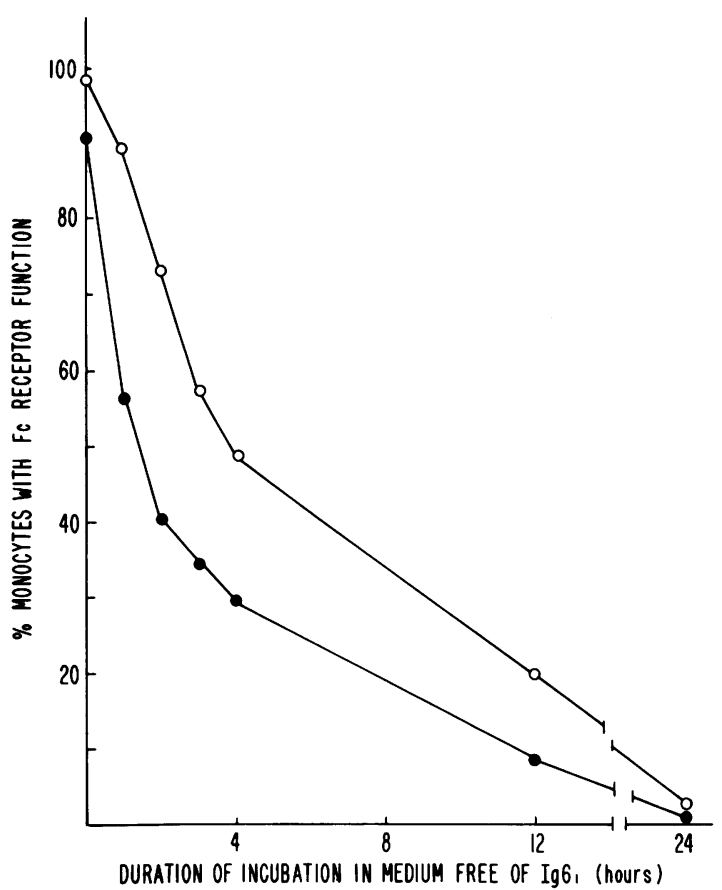

Figure 1 Time-course of the loss of $\mathrm{Fc}_{\mathrm{c}}$ receptor function of monocytes suspended in medium free of IgG after incubation for $1 \mathrm{~h}$ in medium containing heat-treated IgG1 (10 mg/ $\mathrm{ml})$. Monocytes $\mathrm{Fc}$ receptor function assayed: 0 , without trypsin treatment; $O$, after treatment of monocytes with trypsin.

to the presence of monomeric IgG since the loss of $\mathrm{Fc}$ receptor function of monocytes after a $1-h$ incubation with heat-aggregated IgG1 and washing could be blocked by the re-addition of monomeric IgG to the medium during the subsequent 17-h incubation (Fig. 2). Heat-aggregated $\mathrm{Fab}_{2}$ fragments of IgG1 did not alter $\mathrm{Fc}$ receptor function (Table III).

The effect of anti-IgG on Fc receptor function. Fc receptor function of monocytes was markedly diminished by incubation with rabbit anti-IgG antiserum (at dilutions of $1: 250$ to 10,000 ) for 1-2 $\mathrm{h}$. Treatment with trypsin after 10-30 min of incubation partially reversed the loss of $\mathrm{Fc}$ receptor function but after longer incubation the loss of $\mathrm{Fc}$ receptor function was not reversible (Fig. 3). A purified IgG fraction of anti-IgG also had activity, but $\mathrm{Fab}_{2}$ fragments of IgG anti-IgG did not cause a loss of receptor function and, in fact, blocked the reduction of receptor function produced by unaltered anti-IgG (Table IV). Normal nonimmune rabbit serum at similar dilutions did not alter monocyte $F_{c}$ receptor function. Inhibition of $\mathrm{Fc}$ receptor function produced by anti-IgG was blocked by the addition of $1 \mathrm{mg} / \mathrm{ml}$ of monomeric IgG to the incubation medium (data not shown).

The effect of Fc receptor alteration upon phagocytosis and complement receptor function. Monocytes depleted of $\mathrm{Fc}$ receptor function as a consequence of in- 


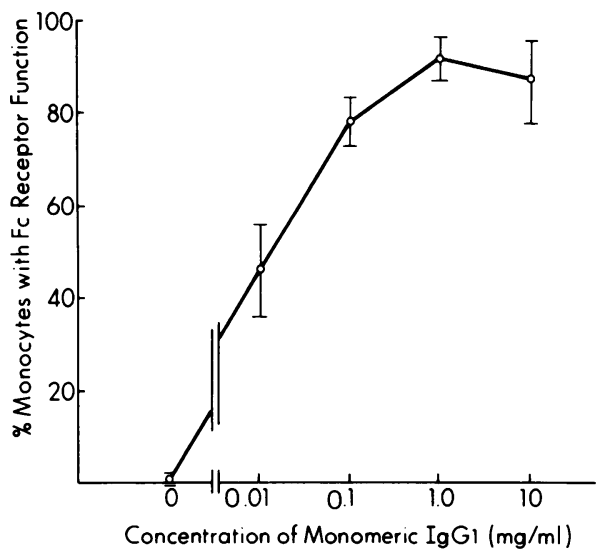

FigURE 2 Fc receptor function of monocytes incubated in medium containing varying amounts of monomeric IgGl for $17 \mathrm{~h}$ after incubation with heat-treated $\operatorname{IgGl}(10 \mathrm{mg} / \mathrm{ml})$ for $1 \mathrm{~h}$.

cubation with IgG1, or anti-IgG, still phagocytosed latex beads and rosetted EC43 normally (data not shown).

The effect of sodium azide on receptor depletion. The loss of $\mathrm{Fc}$ receptor function associated with the adherence of monocytes to plastic coated with monomeric IgGl was markedly inhibited by prior incubation of the cells with sodium azide. Sodium azide did not prevent the loss of receptor function produced by incubation of monocytes with heat-treated IgGl or anti-IgG. However, it did partially block the transformation by which

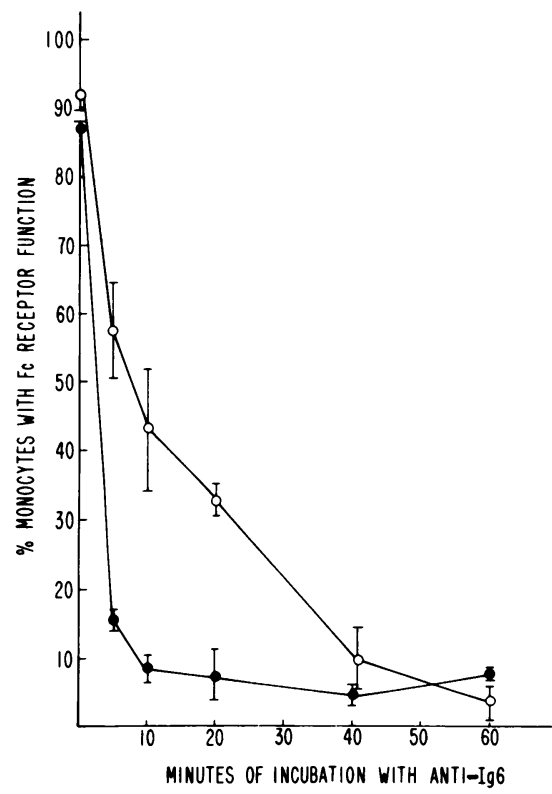

FIGURE 3 Fc receptor function of monocytes incubated with anti-IgG (1:500 dilution) for $1 \mathrm{~h}$. Fc receptor function was either assayed directly $(\bullet)$ or after treatment of monocytes with trypsin (O).
TABLE IV

Effect of Anti-IgG Upon Fc Receptor Function

\begin{tabular}{lc}
\hline Monocytes incubated with & $\begin{array}{c}\text { \% Monocytes with } \\
\text { receptor function }\end{array}$ \\
\hline Anti-IgG antiserum & $6.7 \pm 3.2 * \ddagger$ \\
IgG anti-IgG & $3.7 \pm 1.1 \ddagger$ \\
IgG F $(\mathrm{ab})_{2}$ anti-IgG & $91.0 \pm 5.3$ \\
IgG F(ab) $)_{2}$ anti-IgG, & $82.8 \pm 2.3$ \\
followed by anti-IgG & \\
Medium & $89.3 \pm 5.0$ \\
\hline
\end{tabular}

$* \pm \mathrm{SD}$.

$\ddagger P<0.001$.

receptor loss produced by these reagents became irreversible despite treatment with trypsin (Table V).

The effect of incubation in vitro upon $F c$ receptor function. $\mathrm{Fc}$ receptor function of adherent monocytes was assessed after incubation in N-T with $20 \%$ autologous human serum for $1-4 \mathrm{~d}$. Because monomeric IgG present in serum could alter $F_{c}$ receptor function by nonspecific adherence to the walls of microtiter wells (see above), monocytes were always treated with trypsin just before assay for $F_{c}$ receptor function.

$F_{c}$ receptor function of adherent monocytes incubated in vitro decreased considerably during the first $2 \mathrm{~d}$ of culture (Fig. 40 ) although nearly all monocytes still possessed $\mathrm{Fc}$ receptors detectable after incubation with $\mathrm{EA}_{\text {papain }}$ (Fig. 4, O). If $\mathrm{Fc}$ receptor function was depleted by treatment with anti-IgG, it was restored very slowly in vitro and did not return to the level of undepleted monocytes similarly cultured even after $4 \mathrm{~d}$ (Fig. 5, ๑), but significant restoration of $\mathrm{Fc}$ receptor function could be detected using $\mathrm{EA}_{\text {papain }}$ within $6-12 \mathrm{~h}$ of incubation (Fig. 5, O). This restoration was inhibited by the addition of cycloheximide $(2 \mu \mathrm{g} / \mathrm{ml}$ (Fig. 6 , O) or by the deletion of serum from the incubation medium (Fig. 6, $\Delta$ ).

\section{DISCUSSION}

In these experiments we demonstrated that the $\mathrm{Fc}$ receptor function of human monocytes may be reduced markedly by incubation with IgG in vitro. Loss of receptor function may result either from the reversible saturation of surface $F_{c}$ receptors with IgG or from irreversible loss of receptor function via an energy-dependent process. Monomeric IgG1 in solution inhibits interaction of monocytes with EA presumably by competing with IgG antibody bound to erythrocytes for a limited number of receptor sites, but since binding is of low affinity and rapidly reversible, $\mathrm{Fc}$ receptor function is restored as soon as unbound IgGl monomer is washed away. However, when monocytes are permitted to adhere to a plastic surface coated with mono- 
TABLE V

Effect of Sodium Azide on Depletion of Monocyte Fc Receptor Function Produced by IgGl and Anti-IgG

\begin{tabular}{|c|c|c|c|c|}
\hline & \multicolumn{4}{|c|}{ Percent monocytes with $F c$ receptor function after incubation in medium } \\
\hline & \multicolumn{2}{|c|}{ Without sodium azide } & \multicolumn{2}{|c|}{ With sodium azide } \\
\hline & $\begin{array}{l}\text { Without trypsin } \\
\text { treatment }\end{array}$ & $\begin{array}{l}\text { With trypsin } \\
\text { treatment }\end{array}$ & $\begin{array}{l}\text { Without trypsin } \\
\text { treatment }\end{array}$ & $\begin{array}{c}\text { With trypsin } \\
\text { treatment }\end{array}$ \\
\hline $\begin{array}{l}\text { Monocytes permitted to adhere to wells } \\
\text { coated with IgG1 for } 1 \mathrm{~h}\end{array}$ & $11.7 \pm 2.4^{*}$ & ND & $90.0 \pm 6.9 \ddagger$ & ND \\
\hline $\begin{array}{l}\text { Monocytes incubated with purified aggre- } \\
\text { gates, } 100 \mu \mathrm{g} / \mathrm{ml} \text { for } 3 \mathrm{~h}\end{array}$ & $1.7 \pm 1.5$ & $57.0 \pm 5.3$ & $0.3 \pm 0.6 \S$ & $90.9 \pm 5.0^{\prime \prime}$ \\
\hline Monocytes incubated with anti-IgG for $2 \mathrm{~h}$ & $13.0 \pm 8.2$ & $17.3 \pm 3.6$ & $17.0 \pm 3.6 \S$ & $58.3 \pm 2.3^{\prime \prime}$ \\
\hline
\end{tabular}

meric IgG, the binding of $\mathrm{Fc}$ receptors to $\mathrm{IgGl}$ on the lower surface of the monocyte results in the persistent loss of $\mathrm{Fc}$ receptor function even after unbound IgGl is washed away. A similar diminution in Fc receptor function, designated "modulation" (20), has been noted when murine macrophage (20-22) or human monocytes $(23)$ are permitted to adhere to a plastic surface coated with immune complexes containing IgG.

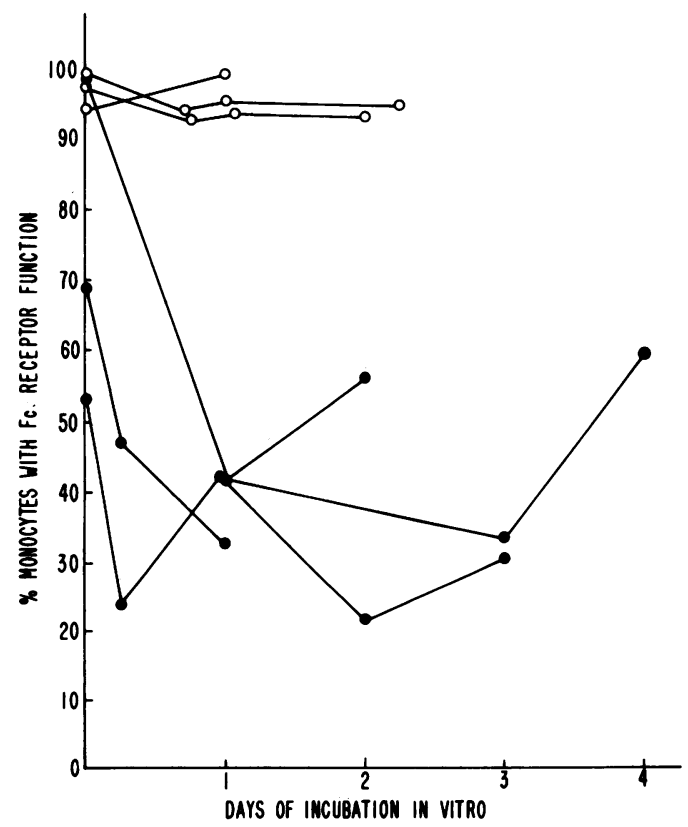

FIGURE 4 Fc receptor function of monocytes incubated in $\mathrm{N}-\mathrm{T}$ with $20 \%$ autologous serum for $1-4 \mathrm{~d}$. Fc receptor function was assessed either with "standard" EA (O) or with EA $_{\text {papain }}(O)$.
Our studies extend prior observations in several respects: (a) "modulation" is probably an energy-dependent process since it is inhibited by sodium azide, (b) modulation of human monocytes can be initiated by adsorbed monomeric IgG as well as by immune complexes, despite the low avidity of binding of soluble IgG monomer to the $\mathrm{Fc}$ receptor (24). We presume either that the concurrent adherence to the monocytes to plastic mechanically stabilizes the interaction of the Fc receptor with adsorbed IgG1 or, alternatively, that

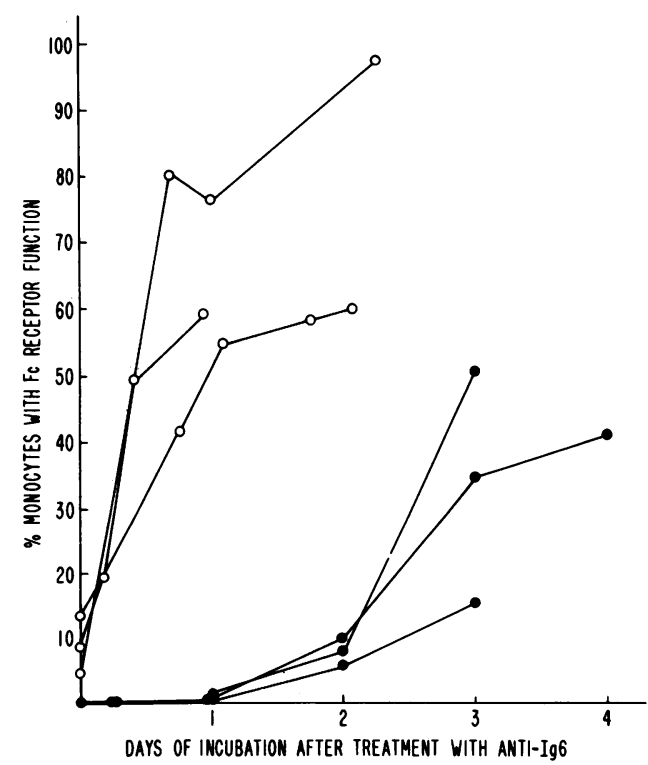

FIGURE 5 Evaluation of the rate of recovery of Fc receptor function after treatment with anti-IgG (1:250) and incubation in N-T with $20 \%$ autologous serum. Fc receptor function was assessed either with standard EA (O) or with $\mathrm{EA}_{\text {papain }}(\mathrm{O})$. 


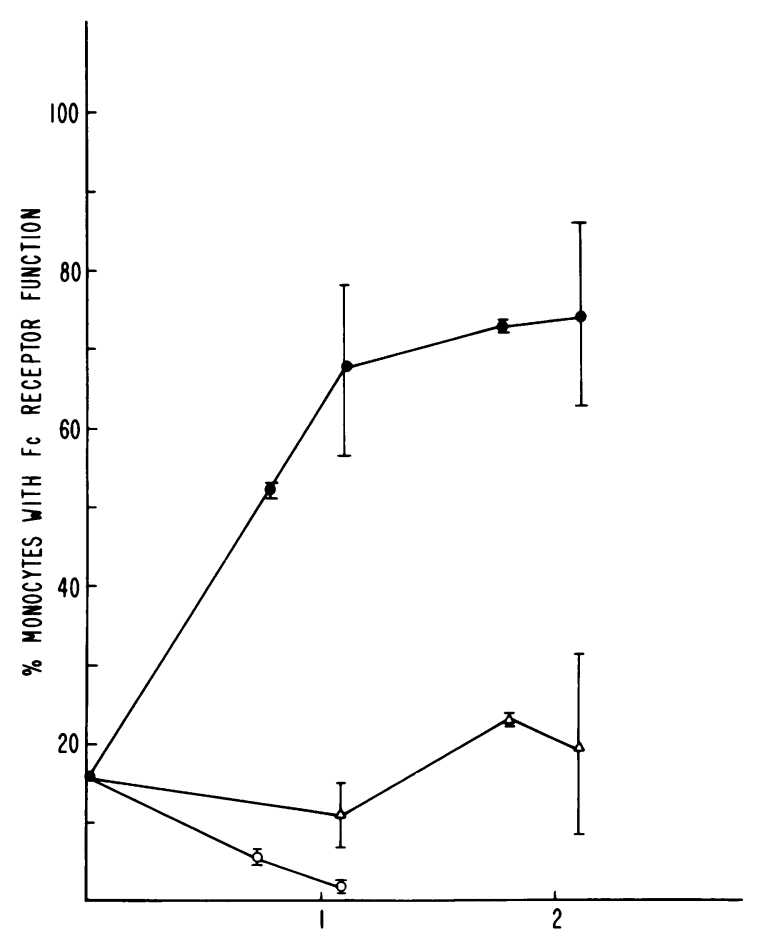

DAYS OF INCUBATION AFTER TREATMENT WITH ANTI-Ig6

FIGURE 6 Evaluation of the rate of recovery of $\mathrm{Fc}$ receptor function after treatment with anti-IgG using $\mathrm{EA}_{\text {papain }}$ to detect $\mathrm{Fc}$ receptor function. Cells were incubated in N-T with $20 \%$ autologous serum with $(O)$ or without $(O) 2 \mu \mathrm{g} / \mathrm{ml}$ of cycloheximide, or with medium without $\operatorname{serum}(\triangle)$.

binding of monomer to plastic alters the conformation of the IgG, permitting firm IgG-Fc receptor binding in the absence of antibody-antigen interaction or aggregation of the IgG and, $(c)$ that modulation can be reversed completely by trypsin, which degrades IgGl, but does not destroy the $\mathrm{Fc}$ receptor (25).

Our findings support the hypothesis $(20,21,23)$ that modulation results from the formation of stable complexes between adsorbed IgG and $\mathrm{Fc}$ receptors that migrate to the site of contact with IgG from other parts of the cell surface (Fig. 7A). Because receptor loss is reversible, it is unlikely that receptor denaturation or internalization is important in the loss of function as has been suggested by others (22). Of practical importance, since similar adsorption of IgG may occur whenever concentrated solutions of IgG are incubated with monocytes adherent to plastic, $\mathrm{Fc}_{\mathrm{c}}$ receptor function of monocytes that have been incubated in medium containing IgG (such as autologous serum) cannot be assessed accurately unless the cells are transferred from the IgG-coated surface or are treated with trypsin to degrade adsorbed IgG.

Because aggregates of IgG are known to bind to the $\mathrm{Fc}$ receptor of mononuclear cells more avidly than
A

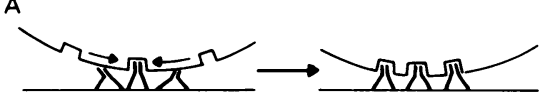

B

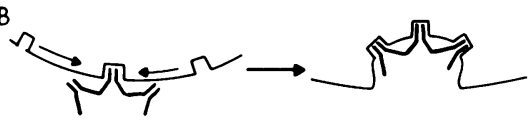

C

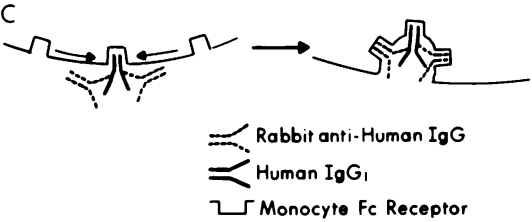

Figure 7 Proposed mechanisms for reduction of Fc receptor function of $(A)$ monocytes incubated in a surface coated with IgGl monomer, (B) for monocytes incubated with aggregated IgGl and (C) for monocytes treated with anti-IgG.

monomeric IgG (24) with a much slower rate of dissociation (26), we presume that the rapid loss of $\mathrm{Fc}$ receptor function following incubation of monocytes with concentrated solutions of purified aggregates results from the saturation of available receptors with IgGl aggregates. We attribute the return of function after trypsin treatment to the degradation of IgGl aggregates still bound to the receptors on the cell membrane. Since function was restored by trypsin, even after incubation with concentrated aggregates for $18 \mathrm{~h}, \mathrm{IgG}-\mathrm{Fc}$ receptor complexes apparently can remain on the membrane surface without ingestion, shedding, or denaturation for prolonged periods.

When monocytes were incubated with lower concentrations of purified aggregates or with heat-treated IgG 1 and then washed to remove contaminating monomeric IgGl, Fc receptor function gradually was lost over a 12-18-h period and could not be restored with trypsin. We propose that delayed loss of $\mathrm{Fc}$ receptor function occurred because smaller amounts of multivalent aggregates bound to the monocyte membrane initially by only a few of the total $\mathrm{F}_{\mathrm{C}}$ fragments available could subsequently bind additional receptors (Fig. 7B). The eventual irreversibility of receptor loss in this instance suggests that these complexes are ingested by monocytes as are other receptor-ligand complexes (27). Alternatively, receptors may be denatured or shed, although there is no data as yet to support these mechanisms.

It is unclear why irreversible receptor loss did not occur when cells were incubated with very high concentrations of IgGl aggregates but it is possible that high concentrations of membrane-bound complex "overload" the cell's capacity to organize the process of ingestion or, alternatively, the binding of multiple $\mathrm{Fc}$ receptors per bound aggregate may be a prerequisite for ingestion, so that if too many IgGl aggregates are bound the 
degree of $\mathrm{Fc}$ receptor binding per aggregate is insufficient to initiate ingestion.

Human monocytes isolated and washed in vitro have been shown to be coated with surface IgG (28). Our findings suggest that binding of anti-IgG to this membrane-bound IgG may initiate binding of $F$ c receptors with the subsequent ingestion of the IgG-anti-IgG complexes. Though the antibody-antigen interaction (rather than IgG-Fc receptor interaction) is responsible for the binding of anti-IgG to the surface of monocytes, receptor loss mediated by anti-IgG appears to proceed by the same mechanism as described above (Fig. 7C), since the loss of $\mathrm{Fc}$ receptor activity is dependent upon membrane binding of IgG-anti-IgG with an intact Fc fragment. The ability to deplete selectively $\mathrm{Fc}_{\mathrm{c}}$ receptor function in vitro permits the quantitative study of the rate of regrowth of receptors in vitro. Such regrowth has been evaluated previously, but the methods used for depleting $\mathrm{Fc}$ receptor function have had substantial limitations $(21,29)$. The methods of depletion described here are simple, specific, and without major morphologic consequences to the treated cells and, thus, appear better suited to the study of membrane receptor dynamics.

The perceived level of $\mathrm{Fc}$ receptor function of monocytes incubated in vitro in these experiments varied depending upon the characteristics of the antibodycoated erythrocytes used to detect receptor function. Fc receptor function detected with erythrocytes coated with IgG anti-D antibody diminished substantially during incubation in vitro, and receptor regrowth after depletion was incomplete after incubation in vitro for $4 \mathrm{~d}$. In contrast, $\mathrm{Fc}$ receptor function detected using erythrocytes treated with papain before antibody sensitization was present in $>90 \%$ of monocytes after $2 \mathrm{~d}$ of incubation in vitro. After depletion with anti-IgG, function was largely restored within $12-24 \mathrm{~h}$, a rate of recovery close to that reported previously $(21,29)$. This recovery was blocked by cycloheximide and, thus, probably required the synthesis of new $\mathrm{Fc}$ receptors in vitro.

We are unable to determine whether these differences in perceived receptor function reflect the presence of two separate populations of $\mathrm{Fc}$ receptors analogous to those reported in the mouse (30), only one of which is detected by standard EA or whether the differences noted reflect only a greater propensity of papain-treated EA for interaction with monocytes possessing a low level of $F_{c}$ receptor function. Whichever is the case, it is clear that receptor function is at least partially restored within $24 \mathrm{~h}$ but that receptor function of monocytes incubated in vitro under the conditions described, whether treated with anti-IgG or not, is diminished compared with uncultured monocytes.

Our studies suggest that the binding and clearance of immune complexes containing IgG by the reticulo- endothelial system may result in the selective depletion of $\mathrm{Fc}$ receptor function. Such a mechanism might account for the decreased clearance of IgG antiD-coated erythrocytes noted in patients with a variety of diseases sharing in common the presence of circulating immune complexes. If $\mathrm{Fc}$ receptor function is selectively depleted as a consequence of immune clearance in vivo, the rate at which the reticuloendothelial system can regenerate receptor function may be an important determinant both of the rate of immune clearance and of the severity of immune-mediated destruction.

\section{ACKNOWLEDGMENTS}

We are deeply indebted to Ms. Janet Batker for technical assistance in these experiments and to Ms. Norma Martell for help in preparation of the manuscript.

Roger Kurlander is supported by the Medical Research Service of the Veterans Administration. This research was supported in part by National Institutes of Health grant RO1 CA-10267-11.

\section{REFERENCES}

1. LoBuglio, A. F., R. S. Cotran, and J. H. Jandl. 1967. Red cells coated with immunoglobulin G: binding and sphering by mononuclear cells in man. Science (Wash. D. C.). 158: $1582-1584$.

2. Huber, H., S. D. Douglas, and H. H. Fudenberg. 1969. The IgG receptor: an immunologic marker for the characterization of mononuclear cells. Immunology. 17: $7-21$.

3. Mollison, P. L., and N. C. Hughes-Jones. 1967. Clearance of $\mathrm{Rh}$ positive red cells by low concentrations of Rh antibody. Immunology. 12: 63-73.

4. Schreiber, A. D., and M. M. Frank. 1972. Role of antibody and complement in the immune clearance and destruction of erythrocytes. I. In vivo effects of IgG and IgM complement-fixing sites. J. Clin. Invest. 51: 575-582.

5. Kurlander, R. J., W. F. Rosse, and G. L. Logue. 1977. Qualitative influence of antibody and complement coating of red cells on monocyte-mediated cell lysis. J. Clin. Invest. 61: 1309-1319.

6. Abramson, N., E. W. Gelfand, J. H. Jandl, and F. S. Rosen. 1970. The interaction between human monocytes and red cells. Specificity for IgG subclasses and IgG fragments. J. Exp. Med. 132: 1207-1215.

7. van Loghem, J. J., E. W. van der Meulen, A. Fleer, M. I. A. van der Hart, A. E. G. Kr von dem Borne, and C. P. Engelfriet. 1977. The importance of the $F_{C}$ receptor for red cell destruction under the influence of non complement binding antibodies in human blood groups. 5th International Convocation of Immunology, Buffalo, N. Y., Karger AG, Basel. 75-84.

8. Frank, M. M., M. I. Hamburger, T. J. Lawley, R. P. Kimberly, and P. H. Plotz. 1979. Defective reticuloendothelial system $\mathrm{Fc}$ receptor function in systemic lupus erythematosus. N. Engl. J. Med. 300: 518-523.

9. Lockwood, C. M., S. Worrledge, A. Nicholas, C. Cotton, and D. K. Peters. 1979. Reversal of impaired splenic function in patients with nephritis or vasculitis (or both) by plasma exchange. N. Engl. J. Med. 300: 524-530.

10. Hamburger, M. I., H. M. Moutsopoulos, T. J. Lawley, and M. M. Frank. 1979. Sjögren's syndrome. A defect in 
reticuloendothelial system $\mathrm{Fc}$ receptor specific clearance. Ann. Intern. Med. 91: 534-538.

11. Cooper, S. M. 1979. N. Engl. J. Med. 300: 1486 (Letter).

12. Dickler, H. B., and H. G. Kunkel. 1972. Interaction of aggregated $\gamma$-globulin with B lymphocytes. J. Exp. Med. 136: $191-196$.

13. Anderson, C. L., and H. M. Grey. 1974. Receptors for aggregated IgG on mouse lymphocytes: their presence on thymocytes, thymus-derived, and bone marrow-derived lymphocytes. J. Exp. Med. 139: 1175-1188.

14. Dixon, R. H., W. F. Rosse, and L. Ebbert. 1975. Quantitative determination of antibody in idiopathic thrombocytopenic purpura. N. Engl. J. Med. 292: 230-236.

15. Stan worth, D. R., and M. W. Turner. 1978. Immunochemical analysis of immunoglobulins and their subunits. In Handbook of Experimental Immunology. D. M. Weir, editor. Blackwell Scientific Publications, Oxford, 3rd edition. 6.20-6.21.

16. Rosse, W. F., G. L. Logue, J. Adams, and J. H. Crookston. 1974. Mechanisms of immune lysis of the red cells in hereditary erythroblastic multinuclearity with a positive acidified serum test and paroxysmal nocturnal hemoglobinuria. J. Clin. Invest. 53: 31-43.

17. Böyum, A. 1968. Isolation of mononuclear cells and granulocytes from human blood. Scand. J. Clin. Lab Invest. 21(Suppl. 97): 77-89.

18. Johnson, W. D., B. Mei, and Z. Cohen. 1977. The separation, longterm cultivation, and maturation of the human monocyte. J. Exp. Med. 146: 1613-1626.

19. Henson, P. M. 1969. The adherence of leucocytes and platelets induced by fixed IgG antibody or complement. Immunology. 16: 107-121.

20. Michl, J., M. M. Pieczonka, J. C. Unkeless, and S. C. Silverstein. 1979. Effects of immobilized immune complexes on Fc- and complement-receptor function in resident and thioglycollate-elicited mouse peritoneal macrophage. J. Exp. Med. 150: 607-621.

21. Rabinovitch, M., R. E. Manesias, and V. Nussenzweig. 1975. Selective phagocytic paralysis induced by immobilized immune complexes.J. Exp. Med. 142: 827-838.

22. Ragsdale, C. G., and W. P. Arend. 1980. Loss of Fc receptor activity after culture of human monocytes on surface bound immune complexes. Mediation by cyclic nucleotides. J. Exp. Med. 151: 32-44.

23. Douglas, S. D. 1976. Human monocyte spreading in vitro inducers and effects on $\mathrm{Fc}$ and $\mathrm{C} 3$ receptors. Cell. Immunol. 21: 344-349.

24. Segal, D. M., and E. Hurwitz. 1977. Binding of affinity cross-linked oligomers of IgG to cell bearing $\mathrm{Fc}$ receptors. J. Immunol. 118: 1338-1347.

25. Davey, M. J., and G. L. Asherton. 1967. Cytophilic antibody I. Nature of the macrophage receptor. Immunology. 12: 13-20.

26. Knutson, D. W., A. Kijlstra, and L. A. van Es. 1977. Association and dissociation of aggregated IgG from rat peritoneal macrophages. J. Exp. Med. 145: 1368-1381.

27. Kaplan, J., and M. L. Nielson. 1979. Analysis of macrophage surface receptors. II. Internalization of $\alpha$-macroglobulin-trypsin complexes by rabbit alveolar macrophages. J. Biol. Chem. 254: 7329-7335.

28. Slease, R. B., R. Wistar, Jr., and I. Scher. 1979. Surface immunoglobulin density on human peripheral blood mononuclear cells. Blood. 54: 72-87.

29. Schmidt, M. E., and S. D. Douglas. 1972. Disappearance and recovery of human monocyte IgG receptor activity after phagocytosis. J. Immunol. 109: 914-917.

30. Walker, W. S. 1976. Separate Fc-receptors for immunoglobulins IgG2a and IgG2b on an established cell line of mouse macrophage. J. Immunol. 116: 911-914. 